\title{
Is postural control different in boys and girls? Comparison between sex
}

\author{
Controle postural é diferente entre meninos e meninas? Comparação entre sexos \\ $\dot{¿}$ Es diferente el control postural entre niños y niñas? Comparación entre sexos \\ Jessica Caroliny de Jesus Neves', Aryane Karoline Vital Souza², Dirce Shizuko Fujisawa ${ }^{3}$
}

ABSTRACT I The purpose of this study was to compare the postural control between eight-year-old boys and girls, considering the nutritional classification and level of physical activity. This was a cross-sectional study, with a sample of 346 participants, classified by the WHO AnthroPlus software, evaluated on the force platform and the Questionnaire Physical Activity for Children. The results demonstrated that girls showed lower values in relation to the opposite sex $(p<0.001)$, in the center of pressure area (COP) (girls: 11.88 vs boys: $15.86 \mathrm{~cm}^{2}$ ), Antero-posterior Amplitude (girl: 5.40 vs boy: $6.05 \mathrm{~cm}$ ), Medial-lateral Amplitude (girl: 3.97 vs boy: $4.40 \mathrm{~cm}$ ), Antero-posterior velocity (girl: 3.98 vs boy: $4.94 \mathrm{~cm} / \mathrm{s}$ ), Medial-lateral velocity (girl: 3.98 vs boy: $4.59 \mathrm{~cm} / \mathrm{s}$ ), Antero-posterior frequency (girl: 0.70 vs boy: $0.84 \mathrm{~Hz}$ ). Physical activity was associated with male sex ( $p=0.001$; $2=11.195$; odds ratio $=0.372$ ). In relation to the center of pressure of sedentary children, girls showed better postural control $(p<0.001)$, but when we analyzed the center of pressure of both sexes who were active there was no statistically significant difference $(p=0.112)$. The $Z$ score of both sexes presented no difference in the center of pressure area ( $p=0.809$ and $p=0.785$ respectively). Girls showed better postural control, while boys are more active; when both sexes performed physical activity COP area was similar. Therefore, special care should be taken when assessing postural control in boys and girls due to their differences in test performance and stage of development. As for interventions, exercise should be considered for better performance of the COP.

Keywords I Postural Balance; Child Development; Anthropometry; Physical Therapy Specialty.
RESUMO I O objetivo foi comparar o controle postural entre os meninos e meninas de oito anos de idade considerando a classificação nutricional e nível de atividade física. Realizou-se um estudo transversal, amostra classificada por meio do software WHO AnthroP/us, avaliada na plataforma de força e pelo Questionário de Atividade Física para Criança. Os resultados mostram que as meninas apresentaram valores menores em relação ao sexo oposto ( $p<0,001)$, quanto à área do centro de pressão (COP) (meninas: 11,88 vs meninos: $15,86 \mathrm{~cm}^{2}$ ), Amplitude Ântero-posterior (meninas: 5,40 vs meninos: $6,05 \mathrm{~cm}$ ), Amplitude Médio-lateral (meninas: 3,97 vs meninos: 4,40cm), Velocidade Ântero-posterior (meinas: 3,98 vs meninos: 4,94cm/s), Velocidade Médio-lateral (meninas: 3,98 vs meninos: 4,59cm/s), Frequência Ântero-posterior (meninas: 0,70 vs meninos: 0,84Hz). A atividade física apresentou associação com sexo masculino $(p=0,001$; $X^{2}=11,195$; Odds Ratio $=0,372$ ). Em relação à área do centro de pressão de crianças sedentárias, as meninas apresentaram melhor controle postural ( $p<0,001)$, porém quando analisado área do centro de pressão de ambos os sexos que são ativos não houve diferença estatisticamente significante $(p=0,112)$. O escore $Z$ de ambos os sexos não teve diferença em relação à área do centro de pressão ( $p=0,809$ e $p=0,785$ respectivamente). Concluiu-se que meninas apresentaram melhor desempenho no controle postural na posição unipodal, enquanto os meninos são mais ativos, quando ambos os sexos realizam atividade física a área do centro de pressão foi similar. Portanto, cuidados especiais devem ser tomados ao avaliar controle postural em meninos e meninas devido às diferenças no desempenho do teste e no estágio de desenvolvimento.

IUniversidade Estadual de Londrina (UEL) - Londrina (PR), Brazil. E-mail: jessica_neves_3@hotmail.com. Orcid: 0000-0001-8269-5448 2Universidade Estadual de Londrina (UEL) - Londrina (PR), Brazil. E-mail: ary_karol@hormail.com. Orcid: 0000-0003-3705-2755

3Universidade Estadual de Londrina (UEL) - Londrina (PR), Brazil. E-mail: dirce_fujisawa@uel.br. Orcid: 0000-0001-8427-2860 
Quanto as intervenções o exercício deve ser considerado para melhor desempenho do COP.

Descritores | Equilíbrio Postural; Desenvolvimento Infantil; Antropometria; Fisioterapia.

RESUMEN | El objetivo de este estudio fue comparar el control postural entre niños y niñas de 8 años de edad según la clasificación nutricional y el nivel de actividad física. Se realizó un estudio transversal; la muestra fue clasificada por el software WHO AnthroPlus y fue evaluada en la plataforma de fuerza y en el Cuestionario de Actividad Física para Niños. Los resultados apuntan que las niñas presentaron valores más bajos en relación al sexo opuesto ( $p<0,001)$; en cuanto al área del centro de presión (COP) (niñas: 11,88 vs. niños: 15,86cm). ${ }^{2}$ ), Amplitud anteroposterior (niñas: 5,40 vs. niños: 6,05cm), Amplitud mediolateral (niñas: 3,97 vs. niños: 4,40cm), Velocidad anteroposterior (niñas: 3,98 vs. niños: $4,94 \mathrm{~cm} / \mathrm{s}$ ), Velocidad media-lateral (niñas: 3,98 vs. niños: 4,59cm/s), Frecuencia anteroposterior (niñas: 0,70 vs. niños: 0,84Hz). Hubo asociación de la actividad física con el sexo masculino ( $p=0,001$; $X^{2}=11,195$; Razón de probabilidad=0,372). En cuanto al área del centro de presión de niños sedentarios, las niñas mostraron un mejor control postural $(p<0,001)$, sin embargo en el análisis del área del centro de presión de ambos los sexos que se encuentran activos, no hubo diferencia estadísticamente significativa $(p=0,112)$. El puntaje $Z$ para ambos los sexos no presentó diferencia en relación al área del centro de presión ( $p=0,809$ y $p=0,785$ respectivamente). Se concluyó que las niñas tuvieron un mejor desempeño en el control postural en la posición unipodal, mientras que los niños fueron más activos, cuando ambos los sexos realizan actividad física, el área del centro de presión fue similar. Por lo tanto, se debe tener especial cuidado al evaluar el control postural en niños y niñas debido a las diferencias en el rendimiento de la prueba y la etapa de desarrollo. En cuanto a las intervenciones, se debe considerar el ejercicio para un mejor desempeño de la COP.

Palabras clave| Equilibrio Postural; Desarrollo Infantil; Antropometría; Fisioterapia.

\section{INTRODUCTION}

Postural control involves the body's ability to perform activities and maintain a state of balance during quiet standing (static posture) and during movement (dynamic posture), providing stability and orientation ${ }^{1}$. Postural control is an aspect of motor control; therefore, it is influenced by the visual, vestibular, and somatosensory systems and by proprioceptive stimuli ${ }^{2}$. The postural control depends on the maturation of the structures involved, as well as on the child's motor experiences ${ }^{3}$.

Motor development is largely affected by experience; as such, the environment and task can cause the individual to vary postural control activity, according to the theory of dynamic systems $s^{4}$. Thus, postural control may be affected by intrinsic factors, such as breathing, heart rate and venous return, age, body mass and interference by extrinsic factors such as exercise ${ }^{5}$.

Regular physical activity is essential for postural control as it promotes stimuli to develop, maintain, or recover balance. Physical activity incorporates and automates some fundamental skills to postural control, due to the stimulation of the neuromuscular structure ${ }^{6}$. However, changes in lifestyle, such as inactivity and inadequate food intake, can lead to obesity in children and adolescents ${ }^{7,8}$ and, consequently, alter the mechanism of postural control ${ }^{8}$.
Childhood obesity can be directly associated with a lack of exercise ${ }^{9}$ as a result of time spent at home, and with a poor diet, thus confirming the influence of the environment on the rise in excess weight in our society. It is known that a child's development is dependent on the environment in which they live and their attitudes reflect that environment ${ }^{10}$. It is also known that excess body weight can negatively influence motor performance ${ }^{11}$.

It is worth noting that boys and girls differ in terms of anatomical and physiological characteristics ${ }^{11,12}$ and that, during development, boys and girls with the same chronological age are at different stages of maturity ${ }^{13}$. The study of this phenomenon is justified due to the lack of literature on the subject as well as the importance of understanding the development of postural control systems to improve performance in clinical practice.

Our hypothesis is that there is a difference in postural control between boys and girls, for intrinsic aspects and/ or performance; if this difference is confirmed, it should be considered both in assessments and in programs for exercise and sports interventions. Early detection of changes in postural control is the first step to prevent conditions predisposing to the appearance of these problems and allow planning of programs that work on postural control; that is, in clinical practice, children of the same age but with different sex go through a period of 
different singularity in postural control and these factors must be considered.

Thus, this study aims to compare postural control in eight-year-old boys and girls, based on their nutritional and activity classification.

\section{METHODOLOGY}

This was a study of cross-sectional design that included a sample with 346 healthy eight-year-old boys and girls from the municipal school district of Londrina in the state of Paraná, Brazil. This age group was selected because of their stage of development of postural control ${ }^{14}$. Participants were selected from a total of 4,880 children enrolled in the second year of primary education in 2013. The sample size was calculated using the formula for finite population with the following parameters: sample error of 5\%, confidence interval of $95 \%$, and overweightobesity ratio of $24 \%$ based on the index of the city of Maringá, $\mathrm{PR}^{15}$. The size of the representative sample was 266 children, already corrected for finite population. An additional 20\% were recruited considering possible losses. The selected schools were from all quadrants of the city, providing stratified sampling.

An informed consent form was sent to the parents or guardians. If they agreed to participate, they also answered the Physical Activity Questionnaire for Children (PAQ-C) ${ }^{16}$. Exclusion criteria were the following: incomplete details; inability to maintain orthostatic position; orthopedic, neurological, and rheumatic disorders; sensory and/or cognitive deficits; history of neuromuscular diseases or previous traumatic orthopedic surgeries; acute or chronic diseases and congenital malformations; complaints of dizziness or vertigo; visual deficit; continuous use of medication; and low weight.

For the anthropometric assessment, height and body mass were measured. Height was measured using a measuring tape (length: $150 \mathrm{~cm}$; precision: $0.1 \mathrm{~cm}$ ). The children stood up with feet together, arms to the side, and ankles touching the wall. Body mass was measured on a scale (Marte, model LC 200) with children standing up with bare feet. The nutritional classification was performed on WHO AnthroPlus ${ }^{17}$, which considers body mass, height, age, and sex and calculates the $Z$ score. $Z$ values less than -2 mean low weight, between -2 and +1 healthy weight, between +1 and +2 overweight, and greater than +2 obesity ${ }^{17}$.

In the postural control assessment, the gold standard force platform (FP) was used ${ }^{18}$. The FP converts the displacement of the center of gravity into electrical signals that can be amplified, recorded, and analyzed. The results provide oscillation measurements such as center of pressure area (COP Area) in $\mathrm{cm}^{2}$, antero-posterior and medial-lateral amplitudes (AP Amp/ML Amp) (cm), antero-posterior and medial-lateral velocity (AP Veloc/ ML Veloc) in cm/s, antero-posterior and medial-lateral frequency (AP Freq/ML Freq) (Hz). The participant was instructed to remain standing upright with bare feet on the FP (BIOMEC 410, EMG System do Brasil ${ }^{\circledast}$ ), arms to the side, and facing a marking placed at eye level at a distance of two meters. The position adopted was single-leg stance for 30 seconds on the preferred leg. The contralateral lower limb remained with the hip in neutral position and the knee flexed at 90 degrees. Three attempts were made, with one-minute rest intervals, and the mean was saved for analysis of all variables. The test was performed in single-leg stance as it is the most difficult (and therefore most sensitive) position ${ }^{19}$. The data acquisition frequency was $100 \mathrm{~Hz}$.

Physical activity was assessed using the PAQ-C Questionnaire; it was developed by Crocker et al. ${ }^{20}$ and reproduced and validated by Guedes and Guedes $(2015)^{16}$. The PAQ-C is composed of 13 questions on sports practice and games, physical activity at school, and leisure activities over the past seven days, including the weekend. Each questionnaire item is scored on a scale of 1 to 5 , where 1 is very sedentary, 2 is sedentary, 3 is moderately active, 4 is active, and 5 is very active. In item 1, which consists of a list of activities, the score is converted into the scale above by dividing the total of points in the item by the number of activities on the list, including the activities added in the "others" section. The same procedure is required for item 13, in which the level of physical activity is scored for each day of the week then all scores are added and divided by seven. The final score is found by calculating the average of the scores for items 1 to 7,9, and 13. The set of variables (age, sex, competitive sports practice, sedentary activities such as TV, computer, and/or videogame, and level of physical activity) was considered independently ${ }^{20}$.

\section{STATISTICAL ANALYSIS}

The data collected were inserted into the program Microsoft Excel and analyzed on SPSS (version 20). The Shapiro-Wilk test was used to verify if the numerical data presented normal distribution. The Mann-Whitney test 
was used for the comparative analysis of postural control between the sexes and the postural control with physical activity of boys and girls. To analyze the association between physical activity and sex, the chi-square $\left(\mathrm{X}^{2}\right)$ test was used. The Kruskal-Wallis test was used to compare the postural control with $Z$ score of boys and girls. Then, odds ratio analysis was applied by means of binary logistic regression. The nutritional classification was represented by descriptive statistics. The significance level was set as $\mathrm{p}<0.05$. The results are presented as medians and quartiles (25\% and $75 \%)$.

\section{RESULTS}

The sample consisted of 180 (52\%) girls and 166 (48\%) boys. In relation to physical activity, 161 (89.4\%) of the girls and 126 (75.9\%) of the boys were sedentary. The nutritional status classification showed that $141(40.7 \%)$ of the children had weight complications, 69 (19.9\%) being overweight (girls 46 (25.6\%), boys $23(13.9 \%))$ and $72(20.8 \%)$ obese (girls $32(17.8 \%)$, boys $40(24.1 \%))$. The statistically significant association was found between being active and male ( $\mathrm{p}=0.001$; $\mathrm{X}^{2}=11.195$; Odds Ratio=0.372).

Regarding postural control (Table 1), the variables $\operatorname{COP}(p=0.000)$, AP Freq $(p=0.000)$, AP Veloc $(p=0.000)$, ML Veloc $(p=0.000), \operatorname{Amp}$ AP ( $p=0.000)$ and ML Amp $(p=0.000)$ were significantly different between the sexes (Figures 1 and 2). The girls showed lower values for the postural control variables compared to boys. Tables 2 and 3 show the COP values for boys and girls according to the nutritional classification and PAQ-C, respectively.

Table 1. The postural control and sexes

\begin{tabular}{|c|c|c|c|c|c|}
\hline & & & Percenti & & \\
\hline & senco & $25 \%$ & Median & $75 \%$ & p \\
\hline $\begin{array}{l}\text { COP area } \\
\left(\mathrm{cm}^{2}\right)\end{array}$ & $\begin{array}{l}\text { Girls } \\
\text { Boys }\end{array}$ & $\begin{array}{c}9.17 \\
11.29\end{array}$ & $\begin{array}{l}11.78 \\
15.86\end{array}$ & $\begin{array}{r}15.89 \\
21.11\end{array}$ & 0.000 \\
\hline $\begin{array}{l}\text { AP Frequency } \\
(\mathrm{Hz})\end{array}$ & $\begin{array}{l}\text { Girls } \\
\text { Boys }\end{array}$ & $\begin{array}{l}0.60 \\
0.70\end{array}$ & $\begin{array}{l}0.70 \\
0.84\end{array}$ & $\begin{array}{l}0.86 \\
1.01\end{array}$ & 0.000 \\
\hline $\begin{array}{l}\text { ML Frequency } \\
(\mathrm{Hz})\end{array}$ & $\begin{array}{l}\text { Girls } \\
\text { Boys }\end{array}$ & $\begin{array}{l}0.73 \\
0.75\end{array}$ & $\begin{array}{l}0.82 \\
0.83\end{array}$ & $\begin{array}{l}0.94 \\
0.98\end{array}$ & 0.062 \\
\hline $\begin{array}{l}\text { AP Velocity } \\
(\mathrm{cm} / \mathrm{s})\end{array}$ & $\begin{array}{l}\text { Girls } \\
\text { Boys }\end{array}$ & $\begin{array}{l}3.32 \\
4.08\end{array}$ & $\begin{array}{l}3.98 \\
4.94\end{array}$ & $\begin{array}{l}4.85 \\
6.12\end{array}$ & 0.000 \\
\hline $\begin{array}{l}\text { ML Velocity } \\
(\mathrm{cm} / \mathrm{s})\end{array}$ & $\begin{array}{l}\text { Girls } \\
\text { Boys }\end{array}$ & $\begin{array}{l}3.43 \\
4.03\end{array}$ & $\begin{array}{l}3.98 \\
4.59\end{array}$ & $\begin{array}{l}4.49 \\
5.30\end{array}$ & 0.000 \\
\hline $\begin{array}{l}\text { AP Amplitude } \\
(\mathrm{cm})\end{array}$ & $\begin{array}{l}\text { Girls } \\
\text { Boys }\end{array}$ & $\begin{array}{l}4.42 \\
4.88\end{array}$ & $\begin{array}{l}5.40 \\
6.05\end{array}$ & $\begin{array}{l}6.64 \\
7.95\end{array}$ & 0.000 \\
\hline $\begin{array}{l}\text { ML Amplitude } \\
(\mathrm{cm})\end{array}$ & $\begin{array}{l}\text { Girls } \\
\text { Boys }\end{array}$ & $\begin{array}{l}3.57 \\
3.86\end{array}$ & $\begin{array}{l}3.97 \\
4.40\end{array}$ & $\begin{array}{l}4.61 \\
5.20\end{array}$ & 0.000 \\
\hline
\end{tabular}

Significant differences $p<0.05$. COP area: center of pressure area; AP Frequency: antero-posterior frequency; ML Frequency: medial-lateral frequency; AP Velocity: antero-posterior velocity; ML Velocity: medial-lateral velocity; AP Amplitude: antero-posterior amplitude; ML Amplitude: mediallateral amplitude.

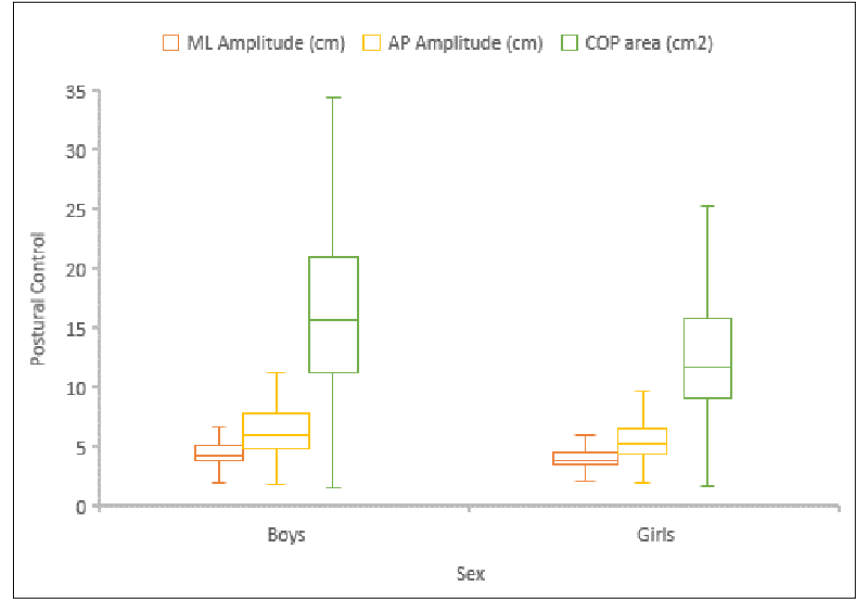

Figure 1. COP area, AP Amplitude and ML Amplitude and sex

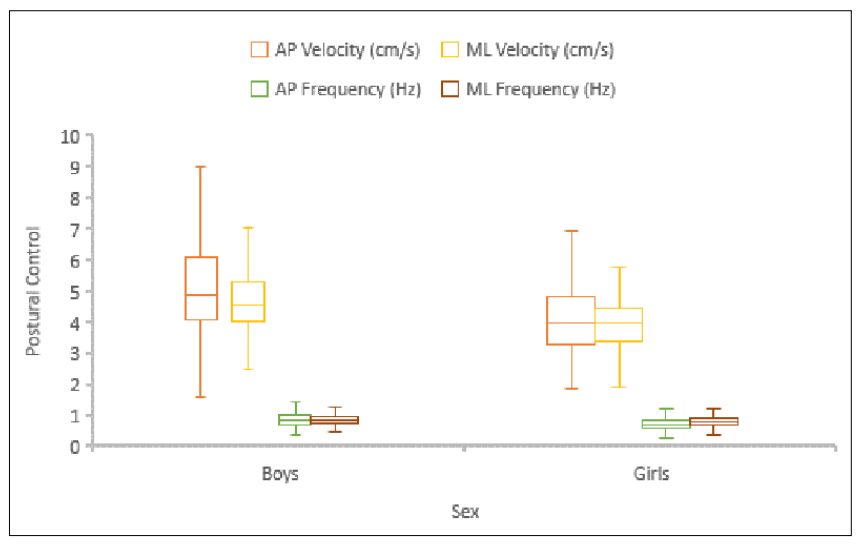

Figure 2. AP Velocity, ML Velocity, AP Frequency, ML Frequency and sex

Table 2. Comparative of the COP area, sexes and nutritional classification

\begin{tabular}{llcccc} 
& & \multicolumn{3}{c}{ Percentil } & \\
\cline { 3 - 5 } & Z Score & $\mathbf{2 5 \%}$ & Median & $\mathbf{7 5 \%}$ & \\
\hline \multirow{3}{*}{ COP area } & Eutrophic & 8.89 & 11.50 & 15.60 & \\
$\left(\mathrm{~cm}^{2}\right)$ - Girls & Overweight & 9.80 & 11.92 & 15.87 & 0.809 \\
& Obese & 9.19 & 11.98 & 16.88 & \\
COP area & Eutrophic & 11.27 & 16.16 & 21.09 & \\
$\left(\mathrm{~cm}^{2}\right)$ - Boys & Overweight & 12.08 & 15.66 & 20.73 & 0.785 \\
& Obese & 10.79 & 14.67 & 21.09 & \\
\hline
\end{tabular}

Significant differences $p<0.05$. COP area: center of pressure area.

Table 3. Comparative of the COP area, sexes and physical activity.

\begin{tabular}{llcccc} 
& & \multicolumn{3}{c}{ COP area $\left(\mathrm{cm}^{2}\right)$} & \\
\cline { 3 - 5 } PAQ-C & Sexes & \multicolumn{3}{c}{ Percentil } & \\
\cline { 3 - 5 } & & $\mathbf{2 5 \%}$ & Median & $\mathbf{7 5 \%}$ & \\
\multirow{2}{*}{ Active } & Girls & 10.90 & 12.21 & 16.77 & 0.112 \\
& Boys & 10.85 & 16.28 & 22.40 & \\
\multirow{2}{*}{ Sedentary } & Girls & 8.99 & 11.58 & 15.66 & \multirow{2}{*}{0.000} \\
& Boys & 11.30 & 15.52 & 21.07 &
\end{tabular}

Significant differences $p<0.05$. COP area: center of pressure area; PAQ-C: Physical Activity Questionnaire for children. 
Binary regression analysis identified a significant association between the variables PAQ-C and sex $(\mathrm{p}=0.000$, Odds Ratio=0.379, CI=0.201-1.717), COP and sex ( $\mathrm{p}=0.000$, Odds Ratio=0.845, CI=0.773-0.924), AP Amp and sex ( $\mathrm{p}=0.030$, Odds Ratio=1.223, CI=1.0111.479), and AP Freq and sex $(\mathrm{p}=0.000$, Odds Ratio $=0.084$, $\mathrm{CI}=0.022-0.321$ ). In other words, physical activity has a protective effect on boys, who were $62.1 \%$ more likely to be active than girls. The female sex influences the COP area, AP Amp, and AP Freq by 15.5\%, 22.3\%, and $91.6 \%$, respectively.

\section{DISCUSSION}

The results of the postural control variables showed different values between the sexes. The girls showed significantly smaller measures than the boys, therefore better postural control (COP) and different compensation mechanisms (AP Freq, AP/ML Veloc, and AP/ML Amp). This means that girls had a lower frequency of oscillation in the antero-posterior feeling when analyzed in the same time interval as boys ${ }^{21}$. The oscillation velocity in both directions was lower in girls, which corresponds to better neuromuscular responses of postural adjustment ${ }^{21}$ The AP/ML amplitude was also smaller, which represents a smaller magnitude of displacement, that is, better stability in girls ${ }^{21}$. This result may be explained by the earlier neurological maturity of the visual, vestibular, and proprioceptive systems in girls ${ }^{22-24}$, which allows them to perform complex balancing tasks more efficiently. During the FP assessments, the girls were also more attentive to explanations and more focused on performance than the boys. These findings corroborate the results of Geldhof et al. ${ }^{22}$, Lee and $\mathrm{Lin}^{25}$, Victorio and Fujisawa ${ }^{26}$ and Kurz et al. ${ }^{27}$ who found greater variability and oscillation in the reference values for static balance of boys compared to girls. The study of Goulème et al. ${ }^{28}$ showed that girls and boys do not proceed in the same way in maintaining their postural control, suggesting that in a more challenging condition girls allocate less energy and have a better postural performance than boys. However, the instrument used for evaluation was the dynamic platform (Multitest Equilibre) and the mean age of the measured children and adolescents was 9 years old.

Clinical tests, such as the Timed Up and Go (TUG) test, the Pediatric Reach Test (PRT), and the Pediatric Balance Scale (PBS) are used to assess dynamic balance.
Butz et al. ${ }^{29}$, observed that clinical tests show no difference in postural control between boys and girls, unlike studies that use the gold standard (i.e., the force platform) as an instrument.

A potential sex difference could be linked with pubertal maturation, which occurs earlier in girls than in boys. As such, puberty rather than chronological age could influence brain maturation and thus the behavior and capabilities involved $^{13}$. Another hypothesis is that the morphological factors of the female body change its distribution of mass, lowering its center of gravity compared to males of the same height and decreasing the values of postural oscillation ${ }^{30}$.

The children of both sexes evaluated in this study had a low level of physical activity; however, when the groups were compared, the boys were more active than the girls. This result agrees with previous studies by Silva and Malina ${ }^{31}$, and Cohen et al. ${ }^{24}$. Some authors cite social and biological factors with the potential to improve fitness. In this sense, the greater involvement of boys can be explained, in part, by social and cultural factors. While boys are oriented toward work-related activities from an early age, girls are oriented toward family-related activities and self-expression ${ }^{24,32}$. From birth, girls and boys are treated differently by adults and society, with boys having more freedom to explore the physical environment ${ }^{32,33}$.

Contrary to expectations, our results showed that the most active children did not necessarily have a smaller COP area, as motor activities provide stimulus to the development of postural control. This fact may be related to the multi-factorial nature of postural control, which does not depend exclusively on the child's physical activities but also on the development of the systems responsible for balance, on anthropometric and external factors, and on concentration and attention during performance.

Regarding the COP area of sedentary children, girls showed better postural control than the boys, possibly due to their more advanced stage of development ${ }^{13,22,23}$. As for the $\mathrm{COP}$ area of active children, there was no significant difference between boys and girls. A possible explanation for this result is that, because physical activity improves postural control, the boys reach similar COP values to those of girls in the same age group, despite the girls' more advanced stage of development as described earlier.

An association has been previously found between being overweight and sex in the South, Southeast, North, and Northeast regions of Brazil ${ }^{34-37}$. These studies also found that girls presented a higher prevalence of weight complications when compared to boys, both in children and adolescents. Regarding nutritional classification, there 
was no statistically significant difference in COP area between girls and boys. The hypothesis is that overweight and obesity have not yet interfered with the mechanism of postural control in this age group.

Therefore, according to the theory of dynamic systems ${ }^{4}$, the individual, environment and task are all important for the development of postural control. The individual refers to anatomical (growth-related), physiological, mechanical, sensorimotor factors that one has; the environment refers to the opportunities of practice, adequate guidance, stimulation, physical activity, and socio-cultural context of the environment, finally, the task concerns the intended objective, its complexity, rules, and strategies, such as physical education classes or physiotherapy ${ }^{6}$.

The results of the regression analysis showed that sex influences PAQ-C, COP, AP Amp, and AP Freq. The limitation of the study was the use of a subjective and memory-dependent instrument to establish the participants' activity classification. Thus, we suggest the use of objective tools to evaluate the physical activity of children in the same age range as our sample or in other age ranges, as well as longitudinal studies.

Modifying the nature of children's activities may predispose an increase in the prevalence of pain in the beginning of their education, which might be a large component of playtime in their daily activities. Older students are expected to have a proportionally greater exposure to computers and study hours, and thus an overload of static postures ${ }^{38}$. Future studies should consider the use of quantitative measures of posture, such as photogrammetry, and to verify the association of postural changes, musculoskeletal pain, physical activity and performance in postural control in children and adolescents.

These results have implications for clinical practice. Regular exercise should be encouraged as a strategy to promote health, prevent weight complications, and stimulate the development of postural control in children.

The results indicate that special care should be taken when assessing postural control in boys and girls due to their differences in test performance and stage of development. As for interventions, exercise should be considered for better performance of the COP.

\section{CONCLUSION}

In the evaluated age range, the girls presented better postural control in relation to COP due to their more developed systems compared to boys. However, the boys were more active than the girls, and when both were active, they presented a similar area of COP, indicating that physical activity affects postural control and that the earlier developmental process in girls ceases to be predominant. Regarding nutritional classification, there was no statistically significant difference in COP area between girls and boys.

\section{REFERENCES}

1. López JR, Fernández NP. Caracterización de la interacción sensorial en posturografía. Acta Otorrinolaringol Esp. 2004;55(2):62-6. doi: 10.1016/S0001-6519(04)78484-8

2. Gazzola JM, Perracini MR, Ganança MM, Ganança FF. Functional balance associated factors in the elderly with chronic vestibular disorder. Braz J Otorhinolaryngol. 2006;72(5):683-90. doi 10.1590/S0034-72992006000500016

3. Sá CDSC, Boffino CC, Ramos RT, Tanaka C. Development of postural control and maturation of sensory systems in children of different ages a cross-sectional study. Braz J Phys Ther. 2018;22(1):70-6. doi:10.1016/j.bjpt.2017.10.006

4. Perone S, Simmering VR. Applications of Dynamic Systems Theory to Cognition and Development: New Frontiers. Adv Child Dev Behav. 2017;52:43-80. doi: 10.1016/bs.acdb.2016.10.002

5. Ekman LL. Neurociências: fundamentos para a reabilitação. Rio de Janeiro: Guanabara Koogan; 2000

6. Gallahue DL, Ozmun JC, Goodway JD. Compreendendo o desenvolvimento motor: bebês, crianças, adolescentes e adultos. 7th ed. Porto Alegre: AMGH; 2013.

7. Rudolf MCJ. The obese child. Arch Dis Child. 2004;89:57-62. doi: 10.1136/adc.2004.059824

8. Neves JCJ, Souza AKV, Fujisawa DS. Controle postural e atividade física em crianças eutróficas, com sobrepeso e obesas. Rev Bras Med Esporte. 2017; 23(3):241-5. doi: 10.1590/1517-869220172303157674

9. Fernandez AC, Mello MT, Tufik S, Castro PM, Fisberg M. Influência do treinamento aeróbio e anaeróbio na massa de gordura corporal de adolescentes obesos. Rev Bras Med Esporte. 2004;10(3):159-64. doi: 10.1590/S1517-86922004000300004

10. Tachdjian MO. Ortopedia pediátrica: diagnóstico e tratamento. São Paulo: Revinter; 2001.

11. Malina RM, Bouchard C. Atividade física do atleta jovem: do crescimento a maturação. São Paulo: Roca; 2002.

12. Caranti DA, Mello MT, Prado WL, Tock L, Siqueira KO, Piano A, et al. Short- and long-term beneficial effects of a multidisciplinary therapy for the control of metabolic syndrome in obese adolescents. Metabolism. 2007;56(9):1293-300. doi: 10.1016/j. metabol.2007.05.004

13. Genc S, Seal ML, Dhollander T, Malpas CB, Hazell P, Silk TJ. White matter alterations at pubertal onset. Neuroimage. 2017;156:28692. doi: 10.1016/j.neuroimage.2017.05.017

14. Assaiante C, Amblard B. An ontogenetic model for the sensorimotor organization of balance control humans. Hum Mov Sci. 1995;14(1):13-43. doi: 10.1016/0167-9457(94)0048-J 
15. Rosaneli CF, Auler F, Manfrinato CB, Rosaneli CF, Sganzerla C, Bonatto $M G$, et al. Evaluation of the prevalence and nutritional and social determinants of overweight in a population of schoolchildren: a cross-sectional analysis of 5,037 children. Rev Assoc Med Bras. 2012;58(4):472-6. doi: 10.1590/ S0104-42302012000400019

16. Guedes DP, Guedes JERP. Medida da atividade física em jovens brasileiros: reprodutibilidade e validade do PAQ-C e do PAQ-A. Rev Bras Med Esporte. 2015;21(6):425-32. doi: 10.1590/1517-869220152106147594

17. World Health Organization. Physical status: the use and interpretation of anthropometry [Internet]. Geneva: WHO; 1995 [cited 2018 Oct 20]. Available from: https://www.who. int/childgrowth/publications/physical_status/en/

18. Mancini M, Horak FB. The relevance of clinical balance assessment tools to differentiate balance deficits. Eur J Phys Rehabil Med [Internet]. 2010 [cited 2021 Mar 09];46(2):239-48. Available from: https://pubmed.ncbi.nlm.nih.gov/20485226/

19. Parreira RB, Boer MC, Rabello L, Costa VSP, Oliveira E JR, Silva RA JR. Age-related differences in centre of pressure measures during one-leg stance are time dependent. J Appl Biomech. 2013;29(3):312-6. doi: 10.1123/jab.29.3.312

20. Crocker PR, Bailey DA, Faulkner RA, Kowalski KC, McGrath R. Measuring general levels of physical activity: preliminary evidence for the Physical Activity Questionnaire for Older Children. Med Sci Sports Exerc. 1997;29(10):1344-9. doi: 10.1097/00005768-199710000-00011

21. Silva RA JR, Pereira C, Oliveira MR, Gil AWO. Equilíbrio postural: avaliação e intervenção por meio de exercícios associados às estratégias de controle neuromuscular. Curitiba: CRV; 2017.

22. Geldhof E, Cardon G, De Bourdeaudhuij I, Danneels L, Coorevits $P$, Vanderstraeten $G$, et al. Static and dynamic standing balance: test-retest reliability and reference values in 9 to 10 years old children. Eur J Pediatric. 2006;165(11): 779-86. doi: 10.1007/ s00431-006-0173-5

23. Sobera M, Siedlecka B, Syczewska M. Posture control development in children aged 2-7 years old, based on the changes of repeatability of the stability indices. Neurosci Lett. 2011;491(1):13-7. doi: 10.1016/j.neulet.2010.12.061

24. Cohen KE, Morgan PJ, Plotnikoff RC, Callister R, Lubans DR. Physical activity and skills intervention: SCORES cluster randomized controlled trial. Med Sci Sports Exerc. 2015;47(4),765-74. doi: 10.1249/MSS.0000000000000452

25. Lee AJY, Lin WH. The influence of gender and somatotype on single-leg upright standing postural stability in children. J Appl Biomech. 2007;23(3):173-9. doi: 10.1123/jab.23.3.173

26. Victorio LVG, Fujisawa DS. Influence of age, sex, and visual information on postural control in children. Motriz. 2019; 25(1): e101978. doi: 10.1590/s1980-6574201900010017

27. Kurz E, Faude O, Roth R, Zahner L, Donath L. Ankle muscle activity modulation during single-leg stance differs between children, young adults and seniors. Eur J Appl Physiol. 2018,118(2):239-247. doi: 10.1007/s00421-017-3764-0

28. Goulème N, Debue M, Spruyt K, Vanderveken C, De Siati DR, Ortega-Solis J, et al. Changes of spatial and temporal characteristics of dynamic postural control in children with typical neurodevelopment with age: results of a multicenter pediatric study. Int J Pediatr Otorhinolaryngol. 2018,133:272-80. doi: 10.1016/j.ijporl.2018.08.005

29. Butz SM, Sweeney JK, Roberts PL, Rauh MJ. Relationships among age, gender, anthropometric characteristics, and dynamic balance in children 5 to 12 years old. Pediatr Phys Ther. 2015;27(2):126-133. doi: 10.1097/PEP.0000000000000128

30. Lemos LFC, Teixeira CS, Mota CB. Uma revisão sobre centro de gravidade e equilíbrio corporal. Rev Bras Cienc Mov. 2009;17(4):83-90. doi: 10.18511/rbcm.v17i4.798

31. Silva RCR, Malina RM. Nível de atividade física em adolescentes do Município de Niterói, Rio de Janeiro, Brasil. Cad Saude Publica. 2000;16(4):1091-7. doi: 10.1590/ S0102-311X2000000400027

32. Woodfield L, Duncan M, Al-Nakeeb Y, Nevill A, Jenkins C. Sex, ethnic and socio-economic differences in children's physical activity. Pediatr Exerc Sci. 2002;14(3):277-85. doi: 10.1123/ pes.14.3.277

33. Levin S, Lowry R, Brown DR, Dietz WH. Physical activity and body mass index among US adolescents: youth risk behavior survey, 1999. Arch Pediatr Adolesc Med. 2003;157(8):816-20. doi: 10.1001/archpedi.157.8.816

34. Wang Y, Monteiro C, Popkin BM. Trends of obesity and underweight in older children and adolescents in the United States, Brazil, China and Russia. Am J Clin Nutr. 2002;75(6):9717. doi: 10.1093/ajcn/75.6.971

35. Silva GAP, Balaban G, Motta MEFA. Prevalência de sobrepeso e obesidade em crianças e adolescentes de diferentes condições socioeconômicas. Rev Bras Saude Matern Infant. 2005;5(1):539. doi: 10.1590/S1519-38292005000100007

36. Soar C, Vasconcelos FAG, Assis MAA, Grosseman S, Luna MEP. Prevalência de sobrepeso e obesidade em escolares de uma escola pública de Florianópolis, Santa Catarina. Rev Bras Saude Matern Infant. 2004;4(4):391-7. doi: 10.1590/ S1519-38292004000400008

37. Krinski K, Elsangedy HM, Hora S, Rech CR, Legnani E, Santos $B V$, et al. Estado nutricional e associação do excesso de peso com gênero e idade de crianças e adolescentes. Rev Bras Cineantropom Desempenho Hum. 2011;13(1):29-35. doi: 10.5007/1980-0037.2012v13n1p29

38. Pereira DSL, Castro SS, Bertoncello D, Damião R, Walsh IA. Relationship of musculoskeletal pain with physical and functional variables and with postural changes in school children from 6 to 12 years of age. Braz J Phys Ther. 2013;17(4):392-400. doi: 10.1590/S1413-35552013005000106 